\title{
Exploring the causality between economic growth, financial development and inflation in sixteen high-income countries
}

\author{
José Alberto Fuinhas $^{1}$; Matheus Koengkan ${ }^{2}$; Matheus Belucio ${ }^{3}$. \\ 1 - CeBER, and Faculty of Economics, University of Coimbra, Coimbra, Portugal. fuinhas@uc.pt. \\ 2 - Rectory, University of Trás-os-Montes and Alto Douro, Vila Real, Portugal. matheuskoen@utad.pt. \\ 3 - CEFAGE-UE, Economy Department, University of Évora, Évora, Portugal. E-mail: \\ matheus.belucio@hotmail.com
}

\begin{abstract}
This paper examined the relationship between economic growth, inflation, stock market development and banking sector development for a panel of sixteen high-income countries for the period from 2001 to 2016, by using the mechanism impulse response functions and Granger causality tests derived from a panel vector autoregressive model. The evidence of bidirectional causality between all variables in the model was found. Overall, feedback and supply-leading theories have been confirmed in the literature. A plus sign in the relationship between the development of the banking sector and the stock market with economic growth was found. Therefore, stock market development and banking sector development stimulate the economy.
\end{abstract}

Keywords: Economic growth; Inflation; Stock market development; Banking sector development; Panel vector autoregressive.

JEL CODE: E5; P24; C23. 


\section{Introduction}

In the last decade, most countries have adopted new development strategies that prioritise the modernisation of the financial sector and link this sector with economic growth. Financial development is a matter of considerable political relevance, especially for the major economies that have recently taken steps to open their capital (Pradhan et al., 2017). In the literature, the financial development sector is disaggregated into various subsections, but this paper focuses only on two: stock market development and banking sector development the level of the banking sector development and the stock market development are among the most critical variables identified in the empirical economic growth literature as correlated with the performance of economic growth in all countries (Fink et al., 2009).

Several studies link financial development and economic growth, but the channels through which inflation affects this relationship and its stability are less exploited (Rousseau and Yilmazkuday, 2009). The inflation targeting (IT) has been increasingly popular in both developed and developing countries for the conduct of monetary policies. Besides, empirical results have shown that IT adoption is linked to the more significant bank's development, equity markets, insurance sectors and bond markets in the developing, but not in industrial economies (Huang and Yeh, 2017).

Based on these facts, the central question of this investigation is: What is the causality between economic growth, inflation, and financial development in high-income countries? How do these causalities work? - With the purpose of answer these questions, this paper investigates the causal relationship between economic growth, inflation and two subcomponents of financial development: the stock market and banking sector development. This causal relationship is analysed through a data panel, which incorporates 16 high-income countries classified by the World Bank over a time horizon of 20012016. The panel vector autoregressive (PVAR) model developed by Holtz-Eakin et al. (1988) was applied as the methodology to capture not only the Granger causality between variables but also the impulse response functions and the variance decomposition to see which variables would suffer shocks in each time interval. 
This investigation is innovative and adds to the literature in various ways: (i) it is the first assessment of the relationship between economic growth, inflation, and financial development;(ii) it uses the PVAR model; and (iii) it focuses on high-income countries, investigating a group of countries that were not previously considered in the literature. Indeed, previous assessments have been focused solely on studying countries in Asia, the Middle East, and Europe. Beyond its academic interest, our empirical analysis is also useful for policymakers of these countries, as it may help in the design of effective policies aimed at promoting the economic growth.

The remainder of this paper is structured as follows. Section 2 is dedicated to the literature review. Section 3 is the data and methodology. Section 4 shows the empirical results. Section 5 shows the discussions, and finally, Section 6 shows the conclusions.

\section{Literature review}

The relationship between financial development and economic growth has been widely discussed among policymakers and researchers (e.g., Ang, 2008; Chow and Fung, 2011; Herwartz and Walle, 2014; Pradhan et al., 2017). The financial system affects and is affected by economic growth (Levine, 1997). A well-developed financial system must be accompanied by the proposition "more finance, more growth" (Law and Singh, 2014). This connection has been the focus of a vast body of theoretical and empirical research, since Schumpeter (1911) seminal work. These various studies (e.g., Beck et al., 2000; Pradhan, 2013; Herwartz and Walle, 2014) examine the effect of financial development and economic growth through different econometric methods, methodologies, data, variables and periods.

Most studies have shown that there is a long-term positive link between financial development indicators and economic growth (Law and Singh, 2014). Subsequently, there are other similar studies for both developed and developing countries. Most of these investigations confirm the existence of a causal relationship between financial development and economic growth (e.g., Enisan and Olufisayo, 2009; Hassan et al., 2011; Menyah et al., 2014; Pradhan et al., 2014a). However, some studies have shown that there is no evidence of causality between financial development and economic growth (e.g., Lucas, 1988; Eng and Habillah, 2011; Mukhopadhyay et al., 2011). 
The empirical studies on this relationship between financial development and economic growth have provided no definite conclusion. At present, there is no consensus among economists about the nature and direction of this relationship. It is known that there are four causality hypotheses present in the literature. These causal hypotheses between financial development and economic growth are the neutrality hypothesis when there is no causality between variables, the supply-leading or demandfollowing hypotheses when exists unidirectional causality between two variables and feedback hypothesis when there is bidirectional causality between the variables. Table 1 presents a synopsis of research on this causal link between financial development in two types of financial markets and economic growth.

Table 1.1 - Revisiting the literature on financial markets and economic growth.

\begin{tabular}{|c|c|c|c|c|}
\hline Article & Period & Country(ies) & Type study & Main finding(s) \\
\hline Ang (2008) & $1960-2001$ & Malaysia & $\mathrm{a}$ & DFH \\
\hline Cheng (2012) & $1973-2007$ & Taiwan & $\mathrm{a}$ & $\mathrm{FBH}$ \\
\hline Chow and Fung (2011) & $1970-2004$ & 69 countries & $\mathrm{b}$ & FBH \\
\hline Coşkun et al. (2017) & 2006 & Turkey & $\mathrm{a}$ & SLH \\
\hline Enisan and Olufisayo (2009) & 1980-2004 & 7 Sub-Saharan African countries & $\mathrm{a}$ & SLH \\
\hline Hou and Cheng (2010) & $1971-2007$ & Taiwan & a & FBH \\
\hline Hsueh et al. (2013) & $1980-2007$ & 10 Asian Countries & $\mathrm{b}$ & SLH \\
\hline Jalil et al. (2010) & $1977-2006$ & China & $\mathrm{b}$ & SLH \\
\hline Kar et al. (2011) & $1980-2007$ & 15 MENA countries & $\mathrm{a}, \mathrm{b}$ & SLH, DFH \\
\hline Kolapo and Adaramola (2012) & $1990-2010$ & Nigeria & $\mathrm{a}$ & SLH \\
\hline
\end{tabular}


Table 1.2 - Revisiting the literature on financial markets and economic growth.

\begin{tabular}{|c|c|c|c|c|}
\hline Article & Period & Country(ies) & Type study & Main finding(s) \\
\hline Liu and Sinclair (2008) & $1973-2003$ & China & a & DFH \\
\hline Menyah et al. (2014) & $1965-2008$ & 21 African countries & $\mathrm{b}$ & SLH \\
\hline Naceur and Ghazouani (2007) & $1979-2002$ & MENA region & $\mathrm{b}$ & SLH \\
\hline Odhiambo (2010) & 1969-2006 & South African & $\mathrm{b}$ & DFH \\
\hline Owusu and Odhiambo (2014) & $1960-2008$ & Nigeria & $a, b$ & SLH \\
\hline Panopoulou (2009) & $1995-2007$ & 5 countries & $a, b$ & $\mathrm{DFH}$ \\
\hline Pradhan (2013) & $1988-2012$ & 16 Asian countries & $\mathrm{a}$ & $\mathrm{SLH}$ \\
\hline Pradhan et al. (2013) & $1988-2012$ & 16 Asian countries & a & SLH \\
\hline Pradhan et al. (2014b) & $1960-2011$ & Asian countries & $\mathrm{b}$ & FBH \\
\hline Pradhan et al. (2014c) & 2011 & 15 Asian countries & $\mathrm{a}$ & DFH \\
\hline Pradhan et al. (2017) & $1991-2012$ & ARF countries & $\mathrm{a}, \mathrm{b}$ & DFH, FBH \\
\hline Wolde-Rufael (2009) & $1966-2005$ & Kenya & $\mathrm{b}$ & $\mathrm{FBH}$ \\
\hline Zhu et al. (2004) & $1973-2007$ & Taiwan & $\mathrm{a}$ & $\mathrm{FBH}$ \\
\hline
\end{tabular}

Notes: DFH: results support the demand-following hypothesis; SLH: results support the supply-leading hypothesis; FBH: results support the feedback hypothesis; NLH: results support the neutrality hypothesis; due to different variables analysed in different studies it was used two letters to specify the causal relationship in study; a: study analyses the relationship between stock market development and economic growth; b: study analyses the relationship between banking sector development and economic growth; MENA: Middle East and North Africa region; ARF: ASEAN Region Forum.

There are several key factors linked to financial development. These factors are: (i) legal origins; (ii) states antique; (iii) barriers to the diffusion of financial technology; (iv) commercial opening; (v) financial openness and globalization; and (vi) institutions. Also, some studies investigate the role of inflation in determining financial development (e.g. Boyd et al., 2001; Kim and Lin, 2010). In the study by Kim and Lin (2010), they concluded that there are a short-term negative performance and a positive long-run relationship between inflation and short-term financial development. However, when data are 
divided into different income and inflation groups, these results can only be analysed in low-income or inflation economies.

That connection between inflation and economic growth has been investigated since inflation control is often viewed as the most crucial goal that monetary policy can aspire to in pursuit of macroeconomic stability, while lack of control has been (e.g., Duttagupta and Cashin, 2008; Rousseau and Yilmazkuday, 2009). Though, there is no consensus on this relationship between inflation and economic growth because the signal minus in the relationship is supportive (e.g., Fischer, 1993; Barro, 1996), but Bruno and Easterly (1998) showed that these results are due to high inflation observations in the underlying data. The high inflation possibly adversely affects financial market operations and thus alters the relationship between financial development and economic growth (Hung, 2003).

The empirical study of Boyd et al. (2001) showed that inflation is negatively correlated with the performance of financial markets, being ignored by the more theoretical literature. Besides, if the government deficit is relatively large, there are several balances, causing high inflation, and in other cases, low inflation. In this situation, these effects of financial development on growth depend mainly on the initial status of equilibrium. In short, if countries have a relatively low initial inflation rate, financial development reduces the rate of equilibrium inflation and promotes economic growth. However, if countries have a relatively high initial inflation rate, the rate of inflation will reduce economic growth (Hung, 2003).

The study by Rousseau and Yilmazkuday (2009) has shown that the lower the growth rates, the more often they are in an environment of high inflation, and financial development is typically suppressed. It has also proved that the adverse effects of inflation are more severe for low-income than for low-income countries. Also, there are studies on the short- and long-run relationship between economic growth, inflation and the stock market development. Pradhan et al. (2015), demonstrated a remarkable short-run and long-run causality connection between the three variables. Besides, there is a unidirectional causality that occurs from economic growth and the stock market for both short-run and long-run inflation. 
A study like ours by Marques et al. (2013) for Portugal, demonstrates that if policymakers intend to stimulate economic growth, they should act in the development of the stock market. Also, the banking system does not seem to have been the engine of economic growth but was a major beneficiary of this growth. Concerning inflation, a control variable in that article showed that inflation causes economic growth, but in a negative way.

In the literature, it has been suggested that the stock market has contributed to economic growth and may be associated with structural factors in the country and the market (Coşkun et al., 2017). Besides, political regimes are essential for the stock market (Francis and Ofori, 2015). In theoretical/empirical studies based on cross-country analysis, they are more sensitive to countries, their estimation methods, variables and proxies studied, methodology, time horizon and the extent to which the variables are associated (Yu et al., 2012). For example, Seven and Yetkiner (2011) show that the relationship between stock market development and economic growth is significant in middle-income and high-income countries.

Briefly, the empirical view rests on the following essential points. Firstly, a literature review was carried out on nexus growth and financial development, concluding that there is no consensus among researchers, policymakers and economists. This is due to sampling types, time horizons, and the type of econometrics associated with research. Second, there are four causal hypotheses present in the literature, provoking disagreement in the numerous articles on the subject. Finally, studies related to the role of economic growth, inflation and the two types of financial markets are explored.

This paper explores the causal relationship between four variables. To our knowledge, few studies have tried to investigate, simultaneously, the link between economic growth, inflation, and the two types of financial markets (stock market and banking sector development). The main innovations of this article are: (i) the sample used with high-income countries; (ii) sophisticated econometrics to address causality issues between variables; and (iii) the empirical approach to address the causality issues presented in this article. 


\section{Data and methodology}

This section refers to the data and methodology applied. The data is described in section 3.1. in which it is possible to see the description of the variables, as well as the sources and the definition of each variable. The methodology is described in section 3.2, and a subsection 3.2.1 has been described with the preliminary tests.

\subsection{Data}

The paper uses annual data, from 2001 to 2016, for 16 high-income countries classified by the World Bank. The countries are Australia, Austria, Greece, Germany, Ireland, Israel, Japan, Norway, Singapore, Spain, United States of America (USA), Poland, Switzerland, Slovenia, China (Hong Kong Special Administrative Region) and Luxembourg. Table 2 describes the variables, sources and summary statistics.

Table 2 - Variables, sources and summary statistics .

\begin{tabular}{|c|c|c|c|c|c|c|c|}
\hline Variable & Definition & Source & Obs & Mean & $\begin{array}{l}\text { Std } \\
\text { Dev }\end{array}$ & Min & $\operatorname{Max}$ \\
\hline LGDPpc & $\begin{array}{l}\text { Real Gross Domestic Product per capita at } \\
\text { prices of } 2010 .\end{array}$ & $\begin{array}{l}\text { World } \\
\text { Bank } \\
\text { Open } \\
\text { Data } \\
(2019)\end{array}$ & 256 & 10.6175 & 0.5321 & 9.0635 & 11.6259 \\
\hline INF & Inflation at the end of the period. & $\begin{array}{l}\text { World } \\
\text { Bank } \\
\text { Open } \\
\text { Data } \\
(2019)\end{array}$ & 256 & 1.8173 & 1.7792 & -4.4781 & 8.3796 \\
\hline SMD & $\begin{array}{l}\text { Stock market development: composite index } \\
\text { created using principal component analysis } \\
\text { (PCA) with the variables market } \\
\text { capitalisation and turnover ratio. }\end{array}$ & $\begin{array}{l}\text { World } \\
\text { Bank } \\
\text { Open } \\
\text { Data } \\
\text { (2019) }\end{array}$ & 256 & $\begin{array}{l}8.22 \mathrm{e}- \\
10\end{array}$ & 1.0204 & -2.4085 & 2.4041 \\
\hline BSD & $\begin{array}{l}\text { Banking sector development: composite } \\
\text { index created with PCA with the variables } \\
\text { domestic credit to the private sector and } \\
\text { domestic credit provided by the financial } \\
\text { sector. }\end{array}$ & $\begin{array}{l}\text { World } \\
\text { Bank } \\
\text { Open } \\
\text { Data } \\
(2019)\end{array}$ & 256 & $\begin{array}{l}5.98 \mathrm{e}- \\
10\end{array}$ & 1.3658 & -15.1895 & 1.9060 \\
\hline
\end{tabular}

Notes: (L) denotes variables in the natural logarithms; Obs. denotes the number of observations in the model; Std.-Dev. denotes the Standard Deviation; Min. and Max. denote Minimum and Maximum; the command sum of Stata was used. 
The GDP per capita at 2010 prices was used as a proxy for economic growth, used in natural logarithms. The variables stock market development and banking sector development were created using PCA. The PCA transforms original sets of variables into smaller sets of linear combinations that account for most of the variance of the original set. In other words, the use of this technique allows removing the essential information from each variable, and it turns into a single composite variable that contains information from the various variables. In this case, the market capitalisation of listed domestic companies (divided by GDP) and turnover ratio were the variables chosen to perform PCA to create stock market development.

It was used the test of Kaiser-Meyer-Olkin of sampling adequacy (Kaiser, 1970) and Bartlett's test for sphericity (Bartlett, 1950) to test the robustness of the variable stock market development (SMD) and the variable banking sector development (BSD). Table 3 shows the results of the tests, both for the development of the stock market and for the banking sector. Regarding banking sector development, was used domestic credit to the private sector (\% GDP) and domestic credit provided by the financial sector $(\%$ GDP). 
Table 3 - Test of sphericity and sampling adequacy.

\section{Construction of SDM}

\section{Bartlett test of sphericity}

\begin{tabular}{lc}
\hline Chi-square & 0.431 \\
\hline Degree of freedom & 1 \\
p-value & 0.511 \\
The determinant of the correlation matrix & 0.998 \\
\hline
\end{tabular}

Kaiser-Meyer-Olkin measure of sampling adequacy

0.500

Construction of BSD

Bartlett test of sphericity

\begin{tabular}{lc}
\hline Chi-square & 350.379 \\
\hline Degree of freedom & 1 \\
p-value & $0.000^{* * *}$ \\
The determinant of the correlation matrix & 0.251 \\
\hline
\end{tabular}

Kaiser-Meyer-Olkin measure of sampling adequacy

0.500

Notes: $* * *$ denotes statistical significance level at $1 \%$; The Stata command factortest was used.

Briefly, the null hypothesis for the Bartlett test of sphericity is that variable is intercorrelated, and in the case of BSD, the null hypothesis was accepted. The correlation matrix is less than 1, all correlations being different from 0 . If all correlations are equal to 0 the value of the determinant of the correlation matrix would be one but, in this case, the test came up with a value of 0.998 meaning that all correlations are different from 0. The Kaiser-Meyer-Olkin Measure of Sampling Adequacy takes a value between 0 and 1 , and if it comes out below 0.5 , the PCA should not be applied. In this case, the KaiserMeyer-Olkin Measure of Sampling Adequacy is 0.5 for both variables meaning the PCA is possible to use. 


\subsection{Methodology}

The best method to analyse the nexus between economic growth, inflation, financial development in 16 high-income countries is the PVAR model. This method was developed by Holtz-Eakin et al. (1988) as an alternative to multivariate simultaneous equation models and introduced by Love and Zicchino (2006). The PVAR model is used in several research fields but is most commonly used by macroeconomists that working with data for many countries and with long time-span (Kroop and Korobilis, 2016). Canova and Ciccarelli (2009) emphasise that PVARs are an excellent way to model how shocks are transmitted across the countries.

According to Abrigo and Love (2015), the PVAR model has an advantage because it treats all variables as endogenous, although the existence of restrictions based on statistical procedures may be imposed on disentangling the impact of exogenous shocks into the system. Other authors such as Antonakakis et al. (2017) pointed that this model has another advantage such as: (i) the PVAR model is useful in the presence of little theoretical information about the relationship between the variables to guide the specification of the model; (ii) this model was created to address the endogeneity problem among the variables of model; (iii) the PVAR model can account for any delayed effects and of the variables under consideration; (iv) this model allows to include country fixed-effects that capture the time-invariant components that may affect the consumption of energy or economic growth and global time effects that affect all countries in the same period of time; and (v) this model can account any global shocks that impact all countries in the same time in the model. The specification of the equation for the first order PVAR, according to Love and Zicchino (2006) can be seen in Equation (1):

$$
z_{i t}=\Gamma_{0}+\Gamma_{1_{1} z_{i t-1}}+f_{i}+d_{c, t}+u_{t}
$$

where, $z_{t}$ is a vector of four variables (e.g., DLGDPpc, DINF, DSMD, DBSD). The use of variables in first-differences follows from PVAR's prerequisite that all variables must be $\mathrm{I}(0) . \Gamma_{0}$ is the vector of constant, $\Gamma_{1_{1} z_{i t-1}}$ in equation designates the matrix polynomial, the fixed effects in the model $f_{i}$, the effects of time are represented for $d_{c, t}$, and the term of random errors $u_{t}$. Since the fixed effects are correlated with the regressions due to delays of the dependent variables, the average differentiation procedure commonly used to eliminate fixed effects would create biased coefficients. To avoid this 
problem, the approach of Love and Zicchino (2006) use a technique called "Helmert Procedure" (Arellano and Bover, 1995), which will also be used in this model.

Before the realisation of PVAR regression, it is advisable to check the properties of the variables. To this end, some preliminary tests were applied, namely:

a. Variance inflation factor (VIF) (Belsley et al., 1980) to check the existence of multicollinearity between the variables in the panel's data;

b. Cross-sectional dependence (CSD-test) to verify the existence of cross-section dependence in the panel data (Pesaran, 2004);

c. 1st-generation unit root test, such as the Augmented Dickey-Fuller (ADF) test (Dickey and Fuller, 1979) and Phillips-Perron (PP) test (Phillips and Perron, 1988) to check the presence of unit roots. The null hypothesis rejection of the two tests is that the variable is I(1);

d. The Hausman test, which determines the presence of heterogeneity, i.e. whether the panel has random effects $(\mathrm{RE})$ or fixed effects $(\mathrm{FE})$ - the null hypothesis of this test is that the best model is RE - the literature mostly uses estimations with FE, but the use of RE is admissible (e.g., Sigmund and Ferstl, 2017; Binder et al., 2005);

e. A Panel VAR lag-order selection that reports the overall model coefficient of determination (Hansen, 1982).

After the PVAR regression, it is necessary to apply the specification tests to verify the characteristics of the model. To this end, some diagnostic tests by Abrigo and Love (2015) will be applied, namely:

f. The Panel Granger causality Wald test, which analyses the causal relationship between variables. The null hypothesis of this test is that the excluded variable does not Granger-cause equation variable;

g. The Eigenvalue stability condition, which verifies the stability condition of PVAR estimates by computing the modulus of each eigenvalue of the model;

h. Forecast-error variance decomposition (FEVD), which computes the forecast-error variance decomposition based on the Cholesky decomposition of the underlying PVAR model. In this test, the standard errors and the confidence intervals are based on the Monte Carlo simulation;

i. Impulse-response function (IRF). The confidence bands of IRFs are estimated using Gaussian approximation and based on the Monte Carlo simulation. 
This section shows the data that will be used, the methodology, and the preliminary and specification tests. In the next section, the results will be shown.

\section{Empirical results}

In line with what was stated earlier, this section shows the outcomes of the preliminary tests, the PVAR model, and specification tests. Indeed, the realisation of these tests is essential in order to identify if the PVAR model is an appropriate methodology for the realisation of this study. To verify the level of multicollinearity and the presence of cross-sectional dependence in the panel's data, the VIF and CSDtests were applied. Table 4 below shows the mean VIF for the variables and the first differences. All values show values below 10, so there are no multicollinearity problems between the variables.

Table 4 - VIF-test.

\begin{tabular}{|c|c|c|c|c|c|}
\hline Variables & VIF & $1 / \mathrm{VIF}$ & Variables & VIF & 1/VIF \\
\hline LGDPpc & \multicolumn{2}{|c|}{ n.a } & DLGDPpc & \multicolumn{2}{|c|}{ n.a } \\
\hline BSD & 1.14 & 0.8746 & DBSD & 1.01 & 0.9885 \\
\hline INF & 1.04 & 0.9628 & DINF & 1.01 & 0.9932 \\
\hline SMD & 1.10 & 0.9060 & DSMD & 1.01 & 0.9917 \\
\hline Mean VIF & \multicolumn{2}{|c|}{1.10} & Mean VIF & \multicolumn{2}{|c|}{1.01} \\
\hline
\end{tabular}

Notes: The Stata command estat VIF was used. L and D denotes variables in the natural logarithms and first-differences of logarithms; n.a denotes not available.

To identify the presence of cross-sectional dependence in the panel's data, the CSD-test was used. In Table 5 it demonstrates the results for the average correlation coefficients of Pesaran (2004) CD test. The null hypothesis of this test is the presence of cross-section independence $\mathrm{CD} \sim \mathrm{N}(0,1)$, and in this case, we can see in Table 5 below, the presence of cross-section dependence in the variables in levels, logarithms, and in the first-differences. 
Table 5 - Pesaran CD-test.

\begin{tabular}{|c|c|c|c|c|}
\hline Variables & CD-test & p-value & Corr & Abs (corr) \\
\hline LGDPpc & 28.10 & 0.000 & 0.641 & 0.710 \\
\hline INF & 16.57 & 0.000 & 0.378 & 0.462 \\
\hline SMD & 15.73 & 0.000 & 0.359 & 0.419 \\
\hline BSD & 11.58 & 0.000 & 0.264 & 0.552 \\
\hline Variables & CD-test & p-value & Corr & Abs (corr) \\
\hline DLGDPpc & 22.13 & 0.000 & 0.522 & 0.524 \\
\hline DINF & 23.46 & 0.000 & 0.553 & 0.556 \\
\hline DSMD & 19.10 & 0.000 & 0.450 & 0.491 \\
\hline DBSD & 2.53 & 0.011 & 0.060 & 0.257 \\
\hline
\end{tabular}

Notes: The Stata command xtcd was used; (L and D) denote variables in natural logarithms and first-differences of logarithms respectively.

However, in the presence of CSD, it is necessary to assess the order of integration of the variables with a 2nd generation unit root test. In accordance, the cross-sectionally augmented IPS (CIPS) test (Pesaran, 2007) was performed. The 1st-generation unit root test MW test (Maddala and Wu, 1999) was used as a complement of the IPS test. The results of these tests can be seen in Table 6 below. 
Table 6 - Panel unit root test.

\begin{tabular}{|c|c|c|c|c|}
\hline & \multicolumn{2}{|c|}{ Maddala and Wu } & \multicolumn{2}{|c|}{ CIPS (Zt-bar) } \\
\hline & without trend & with trend & without trend & with trend \\
\hline LGDPpc & 23.355 & 19.753 & 0.894 & 1.355 \\
\hline BSD & 19.785 & $45.514^{*}$ & 4.291 & 3.269 \\
\hline SMD & $56.330 * * *$ & 42.038 & $-2.399 * * *$ & $-1.942 * *$ \\
\hline INF & $86.167 * * *$ & $88.455 * * *$ & $-1.961 * *$ & -0.882 \\
\hline DLGDPpc & $98.784 * * *$ & $64.691 * * *$ & $-3.275^{* * *}$ & $-1.577 *$ \\
\hline DBSD & $197.347 * * *$ & $160.136 * * *$ & $-3.991 * * *$ & $-3.620 * * *$ \\
\hline DSMD & $243.348 * * *$ & $199.425 * * *$ & $-7.366^{* * *}$ & $-5.063 * * *$ \\
\hline DINF & $409.183 * * *$ & $322.421 * * *$ & $-7.226^{* * *}$ & $-4.904 * * *$ \\
\hline
\end{tabular}

Notes: $* * *, * *, *$ denote statistical significance at $1 \%, 5 \%, 10 \%$ level, respectively; Pesaran (2007) panel unit root test (CIPS) assumes that cross-sectional dependence is in form of a single unobserved common factor and H0: series is I(1); to compute this test, the Stata command multipurt was used.

The results of unit root tests, show that none of the variables is I(2), although they show that some of them may be in the borderline between the $\mathrm{I}(0)$ and $\mathrm{I}(1)$ order of integration (i.e., all variables in the first-differences and some variables in the level, such as BSD, and INF).

After the realisation of the unit root test, the next step is to assess the presence of individual effects in the model. To this end, the Hausman test, confronting random (RE) and fixed effects (FE), was used. The null hypothesis of this test is that the difference in coefficients is not systematic, (i.e., random effects are the most suitable estimator). The Hausman test indicates that the null hypothesis should be rejected $\left(\operatorname{chi} i^{2}(3)=6.46^{*}\right.$, statistically significant at $10 \%$ level $)$ and that a fixed-effects model is the most appropriate for this analysis. 
To report the overall model coefficients of determination, the lag-order section was calculated. The overall coefficient of determination (CD), Hansen's J statistic (J), p-value (Jp-value), MMSC-Bayesian information criterion (MBIC), MMSC-Akaike information criterion (MAIC), and MMSC-Hannan and Quinn information criterion (MQIC) were computed. This step is mentioned in the methodology section as it is followed by Koengkan et al. (2020). Table 7 shows the results of the PVAR lag-order selection.

Table 7 - PVAR Lag-order selection.

\begin{tabular}{|c|c|c|c|c|c|c|}
\hline Lag & CD & $\mathbf{J}$ & J p-value & MBIC & MAIC & MQIC \\
\hline 1 & 0.9875 & 88.5856 & 0.0226 & -229.4824 & -39.41431 & -116.6472 \\
\hline 2 & 0.9722 & 69.1855 & 0.0242 & -169.3655 & -26.81442 & -84.73911 \\
\hline 3 & 0.9863 & 40.1307 & 0.1531 & -118.9033 & -23.8693 & -62.48576 \\
\hline 4 & 0.9085 & 17.7099 & 0.3411 & -61.80703 & -14.29002 & -33.59825 \\
\hline
\end{tabular}

Note: The Stata command pvarsoc was used.

Four maxlags were used in the PVAR lag-order, totalizing 144 observations, 16 panels, and an average of number $\mathrm{T}$ of 9 . Indeed, before the PVAR estimation, it is necessary to choose the specification that satisfies the Hansen's J statistics, which tests for the overidentification criterion, which means that the specification first needs to "pass" this test before choosing between the lag length that minimises the MBIC, MAIC and MQIC. However, the most often the lag length is chosen by focusing on the MAIC criterion, that is supported by Serena and Perron (2001). The PVAR lag-order selection is focusing on the MAIC criterion points to the use of 1 lag or 2 lags in the PVAR model. After the realisation of preliminary tests, the PVAR regression was computed. Table 8 shows the results of the PVAR model. The lag length (1) and (2), indicated by Panel VAR lag-order selection were used in the PVAR estimation. 
Table 8 - PVAR model results.

\begin{tabular}{|c|c|c|c|c|c|}
\hline & \multicolumn{2}{|c|}{ 1/5 instrumental lags } & \multicolumn{3}{|c|}{ 1/5 instrumental lags } \\
\hline & \multicolumn{2}{|r|}{$1 \mathrm{Lag}$} & \multicolumn{3}{|c|}{2 Lags } \\
\hline $\begin{array}{l}\text { Response of } \\
\text { DLGDPpc to: }\end{array}$ & Coefficient & $\begin{array}{l}\text { Heteroskedasticity adjusted } \\
\text { t-statistics }\end{array}$ & Coefficient & \multicolumn{2}{|c|}{$\begin{array}{c}\text { Heteroskedasticity adjusted } \\
\text { t-statistics }\end{array}$} \\
\hline DLGDPpc & 0.3971 & 8.82 & 0.6146 & 4.43 & $* * *$ \\
\hline DINF & -0.0060 & -7.25 & -0.0054 & -2.88 & $* * *$ \\
\hline DSMD & 0.0358 & 7.43 & -0.0258 & -2.65 & $* * *$ \\
\hline DBSD & 0.0014 & 4.49 & -0.0024 & -1.94 & $* *$ \\
\hline $\begin{array}{c}\text { Response of DINF } \\
\text { to: }\end{array}$ & Coefficient & $\begin{array}{c}\text { Heteroskedasticity adjusted } \\
\text { t-statistics }\end{array}$ & Coefficient & $\begin{array}{r}\text { Heteroske } \\
\mathrm{t} \text { - }\end{array}$ & idjusted \\
\hline DLGDPpc & 25.544 & 7.75 & 21.9057 & 3.33 & $* * *$ \\
\hline DINF & -0.3277 & -5.70 & -0.3800 & -4.38 & $* * *$ \\
\hline DSMD & 3.3607 & 13.34 & -1.3505 & -2.36 & $* *$ \\
\hline DBSD & 0.1282 & 6.44 & -0.2054 & -2.38 & $* *$ \\
\hline $\begin{array}{c}\text { Response of DSMD } \\
\text { to: }\end{array}$ & Coefficient & $\begin{array}{c}\text { Heteroskedasticity adjusted } \\
\text { t-statistics }\end{array}$ & Coefficient & $\begin{array}{r}\text { Heteroske } \\
\mathrm{t} \text { - }\end{array}$ & idjusted \\
\hline DLGDPpc & 0.8037 & 1.86 & -0.6902 & -0.92 & \\
\hline DINF & -0.0119 & -1.66 & 0.0268 & 2.16 & $* * *$ \\
\hline DSMD & -0.2325 & -10.70 & -0.1514 & -2.05 & $* *$ \\
\hline DBSD & 0.0189 & 7.88 & 0.0386 & 12.02 & $* * *$ \\
\hline $\begin{array}{c}\text { Response of DBSD } \\
\text { to: }\end{array}$ & Coefficient & $\begin{array}{c}\text { Heteroskedasticity adjusted } \\
\text { t-statistics }\end{array}$ & Coefficient & $\begin{array}{r}\text { Heteroske } \\
\mathrm{t} \text { - }\end{array}$ & adjusted \\
\hline DLGDPpc & 1.2172 & 1.61 & 13.9535 & 3.74 & $* * *$ \\
\hline DINF & 0.0101 & 0.92 & -0.1331 & -2.24 & $* *$ \\
\hline DSMD & -0.0170 & -0.38 & -0.5850 & -1.69 & $*$ \\
\hline \multirow[t]{3}{*}{ DBSD } & -0.3505 & -4.38 & -0.0552 & -1.28 & \\
\hline & \multicolumn{5}{|c|}{ Test of overidentifying restriction: Hansen's J } \\
\hline & \multicolumn{2}{|c|}{ Chi2(64) $=93.430$} & $\begin{array}{c}\text { Chi2 }(48)= \\
62.416\end{array}$ & & \\
\hline
\end{tabular}

Note: $* * *, * *$, and $*$ denote statistical significance level at $1 \%, 5 \%$, and $10 \%$, level; (D) denotes variables in the firstdifferences of logarithms; The Stata command pvar with one lag was used. Instruments: $1(1 / 5)$ and 2 (1/5); The option 
The results of PVAR regression using 1/5 lags on the instruments and 1 Lag included in the dependent variables list, points to the existence of endogeneity in the variables. The lagged variables in all PVAR equations are at least statistically significant at $1 \%$ and $10 \%$ level. Moreover, the use of $1 / 5$ lags on the instruments and 1 Lag, produces a Hansen's J statistics connected with a $\operatorname{chi}^{2}(64)=93.430$ at $1 \%$ levels, which in this context refers to the case where we with confidence can reject the null hypothesis which states that the overidentification restrictions are valid, thus making the specification invalid. The PVAR regression using 1/5 lags on the instruments and 2 Lags included in the dependent variables list, also points to the existence of endogeneity in the variables. Indeed, the lagged variables in all PVAR equations are at least statistically significant at $1 \%$ and $5 \%$ level. Indeed, this specification produces a Hansen's $\mathrm{J}$ statistics connected with a $c h i^{2}(48)=62.416^{*}$ at $10 \%$ levels, which in this context refers to the case where we with confidence can not reject the null hypothesis which states that the overidentification restrictions are not valid, thus making the specification valid.

For this reason, it was opted to use the PVAR regression using 1/5 lags on the instruments and 2 Lag. Additionally, only the variables in the first-differences were used in the PVAR regression because the respective model requires that all variables be I(0) (see Table 6). In order to verify the robustness of the PVAR model, the eigenvalue stability condition was applied. Table 9 displays the graph of the eigenvalue stability condition. 
Table 9 - Eigenvalue stability condition.

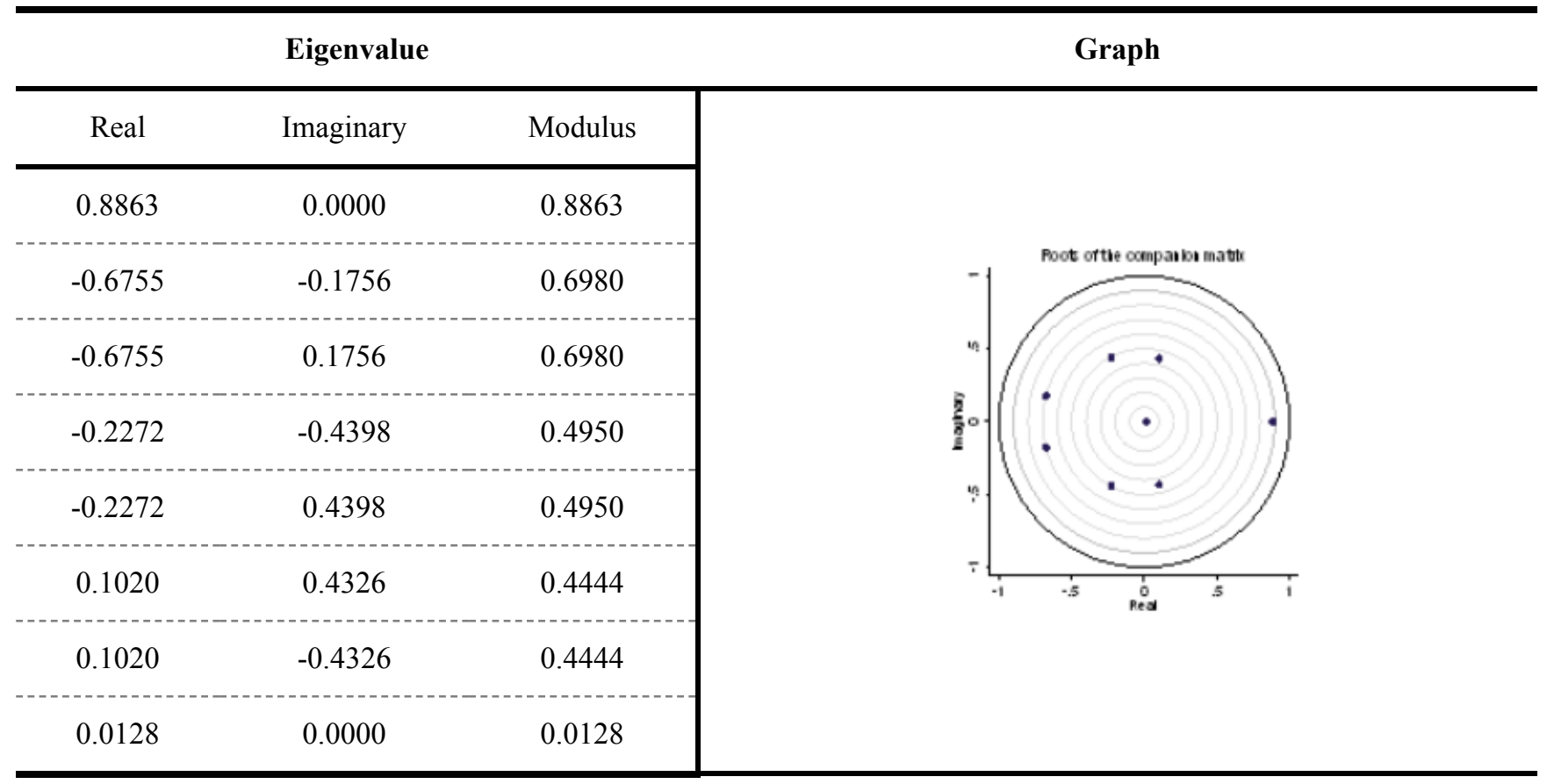

Notes: The Stata command pvarstable was used.

The eigenvalue test points out that the PVAR model is stable, because all eigenvalues are inside the unit circle, satisfying the stability condition of the test (e.g., Hamilton, 1994; Lutkephol, 2005). After the eigenvalue test, the Panel Granger causality Wald test was used to analyse the causal relationship between the variables in the PVAR model. Table 10 shows the results of the Panel Granger causality Wald test. 
Table 10 - Panel Granger causality Wald test

\begin{tabular}{|c|c|c|c|c|c|}
\hline Equation & Excluded & $\mathrm{Chi}^{2}$ & Df & \multicolumn{2}{|c|}{ Prob $>$ chi $^{2}$} \\
\hline \multirow{4}{*}{ DLGDPpc } & DINF & 38.638 & 2 & 0.000 & $* * *$ \\
\hline & DSMD & 19.329 & 2 & 0.000 & $* * *$ \\
\hline & DBSD & 5.770 & 2 & 0.056 & $* *$ \\
\hline & All & 122.299 & 6 & 0.000 & $* * *$ \\
\hline \multirow{4}{*}{ DINF } & DLGDPpc & 18.265 & 2 & 0.000 & $* * *$ \\
\hline & DSMD & 80.466 & 2 & 0.000 & $* * *$ \\
\hline & DBSD & 7.915 & 2 & 0.019 & $* *$ \\
\hline & All & 182.381 & 6 & 0.000 & $* * *$ \\
\hline \multirow{4}{*}{ DSMD } & DLGDPpc & 45.447 & 2 & 0.000 & $* * *$ \\
\hline & DINF & 9.892 & 2 & 0.007 & $* * *$ \\
\hline & DBSD & 156.073 & 2 & 0.000 & $* * *$ \\
\hline & All & 365.563 & 6 & 0.000 & $* * *$ \\
\hline \multirow{4}{*}{ DBSD } & DLGDPpc & 14.392 & 2 & 0.001 & $* * *$ \\
\hline & DINF & 5.574 & 2 & 0.062 & $*$ \\
\hline & DSMD & 5.010 & 2 & 0.082 & $*$ \\
\hline & All & 64.583 & 6 & 0.000 & $* * *$ \\
\hline
\end{tabular}

Notes: ${ }^{* * *}, * *$, and $*$ denote statistical significance level at $1 \%, 5 \%$, and $10 \%$ respectively; (D) denotes variables in the first-differences of the logarithms; the Stata command pvargranger was used.

The results of the Panel Granger causality test above, indicate that there is a bidirectional causality among all variables of the PVAR model, with a significance at $1 \%, 5 \%$, and $10 \%$ level. Figure 1 summarises the causalities between the variables. Indeed, this figure was based on results from Panel Granger causality Wald test (see Table 10) and the results of PVAR estimation (see Table 8). 
Figure 1 - Summary of causality of the variables.

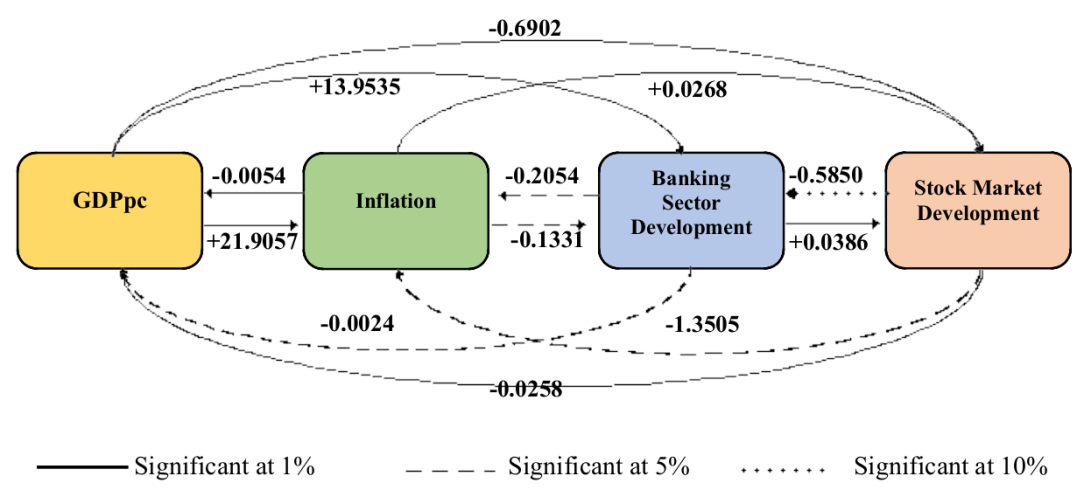

After the Granger causality Wald test, the FEVD needs to be computed. Table 11 shows the outputs of FEVD test.

Table 11.1 - Forecast-error variance decomposition (FEVD).

\begin{tabular}{|c|c|c|c|c|}
\hline \multirow{2}{*}{ Response variable and Forecast horizon } & \multicolumn{4}{|c|}{ Impulse Variable } \\
\hline & DLGDPpc & DINF & DSMD & DBSD \\
\hline \multicolumn{5}{|l|}{ DLGDPpc } \\
\hline 1 & 1 & 0 & 0 & 0 \\
\hline 2 & 0.7451 & 0.2118 & 0.0421 & 0.0007 \\
\hline 5 & 0.7568 & 0.1703 & 0.0634 & 0.0093 \\
\hline 10 & 0.7597 & 0.1756 & 0.0529 & 0.0116 \\
\hline \multicolumn{5}{|l|}{ DINF } \\
\hline 1 & 0.1000 & 0.8999 & 0 & 0 \\
\hline 2 & 0.0773 & 0.8024 & 0.1152 & 0.0049 \\
\hline 5 & 0.2232 & 0.5774 & 0.1660 & 0.0332 \\
\hline 10 & 0.2491 & 0.5546 & 0.1569 & 0.0393 \\
\hline
\end{tabular}


Table 11.2 - Forecast-error variance decomposition (FEVD).

\begin{tabular}{|c|c|c|c|c|}
\hline \multirow{2}{*}{ Response variable and Forecast horizon } & \multicolumn{4}{|c|}{ Impulse Variable } \\
\hline & DLGDPpc & DINF & DSMD & DBSD \\
\hline \multicolumn{5}{|l|}{ DSMD } \\
\hline 1 & 0.0294 & 0.0849 & 0.8855 & 0 \\
\hline 2 & 0.2112 & 0.0644 & 0.6870 & 0.0372 \\
\hline 5 & 0.2852 & 0.0888 & 0.5851 & 0.0406 \\
\hline 10 & 0.3336 & 0.0970 & 0.5299 & 0.0392 \\
\hline \multicolumn{5}{|l|}{ DBSD } \\
\hline 1 & 0.0039 & 0.0048 & 0.0016 & 0.9896 \\
\hline 2 & 0.0093 & 0.0420 & 0.0013 & 0.9472 \\
\hline 5 & 0.0984 & 0.0415 & 0.0382 & 0.8217 \\
\hline 10 & 0.1207 & 0.0447 & 0.0472 & 0.7871 \\
\hline
\end{tabular}

Note: The Stata command pvarfevd was used; (D) denotes variables in the first-differences of logarithms.

The results of the decomposition of the prediction-error variation represent how a variable responds to shocks in specific variables (e.g., Koengkan et al., 2020; Koengkan et al., 2019). The results are consistent with the Hausman test and the impulse-response functions. When we look at the table in detail, we come across new situations. Then, ten periods after a shock on DLGDPpc, the variable explains $76 \%$ of forecast error variance, DINF explains $18 \%$, DSMD explains $6 \%$, and DBSD 1\%. The variable DINF ten periods after a shock explains 55\%, DLGDPpc explains 25\%, DSMD explains 16\%, and DBSD explains 4\%. The variable DSMD, one period after a shock explains $88 \%$, DLGDPpc after ten periods explain 33\%, DINF explains 10\%, and DBSD after five periods explain 4\%. The variable DBSD one period after a shock explains $98 \%$ the forecast error variance, DLGDPpc ten periods after a shock explains 12\%, DINF explains 4\%, and DSMD explains 5\%. Figure 2 shows the impulse response functions. 
Figure 2 - Impulse-response functions; the Stata command pvarirf was used.

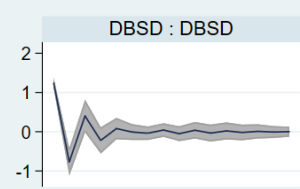

DSMD : DBSD

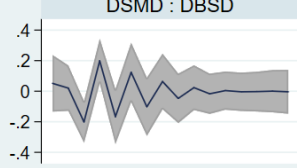

DINF : DBSD

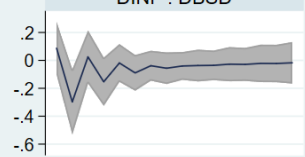

DLGDPpcConst : DBSD

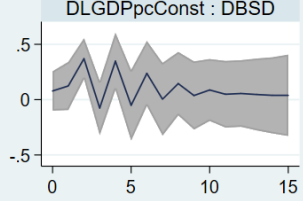$$
\text { (1) }
$$

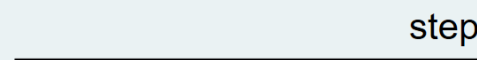

$95 \% \mathrm{Cl}$
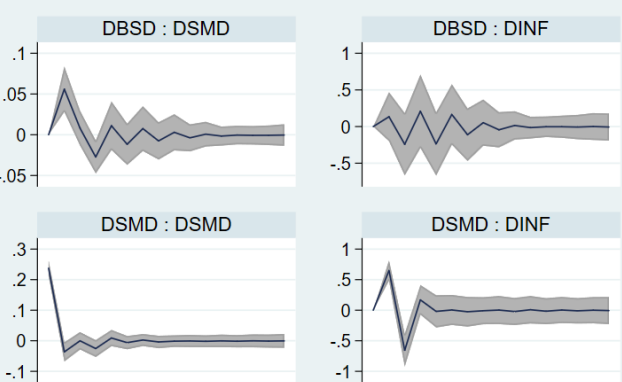

DINF : DSMD

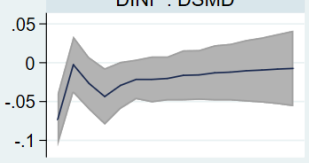

DLGDPpcConst : DSMD

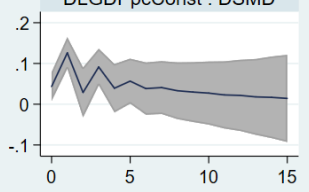

step
DSMD : DINF

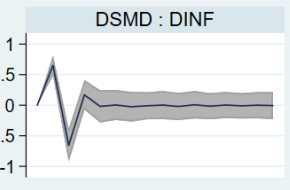

DINF : DINF

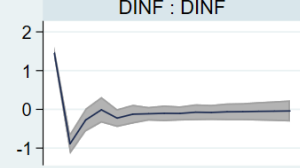

DLGDPpcConst : DINF

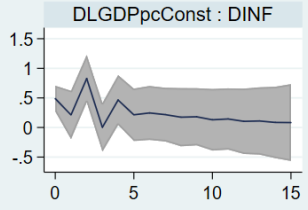

Orthogonalized IRF

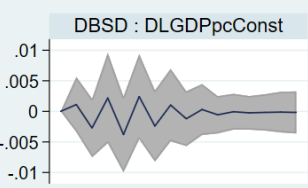

DSMD : DLGDPpcConst
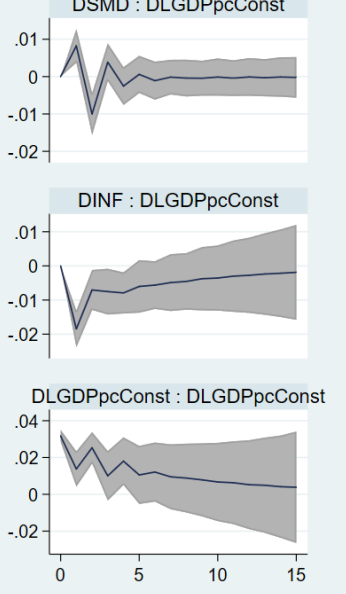

impulse : response

In the long run, all variables converge to equilibrium, supporting that the variables of the model are $\mathrm{I}(0)$. Then, the impulse-response functions are in concordance with FEDV test. The next section will show the discussion of the empirical results.

\section{Discussion}

The preliminary tests that check the characteristics of variables point to the presence of lowmulticollinearity, cross-sectional dependence, stationarity in the first-differences of variables, the fixed effects in the model, and the need to use the lag length (1) or (2) in the PVAR regression.

The PVAR regression using 1/5 lags on the instruments and 2 Lags included in the dependent variables list, indicated that the variables DINF, DSMD, and DBSD have a negative impact on variable DLGDPpc. The variable DLGDPpc exerts a positive impact on variable DINF, while the variables DSMD and DBSD have a negative impact. The variable DSMD is positively impacted by the variables DINF and DBSD. Moreover, the variable DLGDPpc exert a positive impact on DBSD, while the variables DINF and DSMD exerts a negative impact (see Table 8 and Figure 1). 
The outcomes of specification indicated the presence of a bidirectional relationship between the variables DLGDPpc and DINF, DLGDPpc and DSMD, DBSD and DLGDPpc, DINF and DSMD, DBSD and DINF, and DSMD and DBSD. The PVAR model is stable. Two periods after the shock, the variables themselves explained almost all the forecast error variance, and the impulse - response functions of all variables converge to equilibrium, supporting that the variables of the model are I (0) (see Tables 9, 10, 11, and Figure 2).

Are the empirical finds of this investigation in keeping with the literature? What are the possible explanations for the causality between the variables?

Economic growth can be affected by several factors. The theoretical answers are diverse on which the correct model to be used (Petkovski and Kjosevski, 2014). It is known that different countries and economic groups can and will produce different results. Our research shows that for high-income countries, they indicate bidirectional causality between inflation and GDP. These results are in line with the studied by Macchiarelli (2013), for European countries, and Belucio (2019) who studied 19 highincome countries. The acceleration of inflation generates slow development, which is detrimental to any economy. Besides, inflation causes labour to become cheaper. In an excellent economic scenario (which is routine in many rich countries), the increase in GDPpc can cause inflation. In these cases, the stimuli are perceived by the demand side.

We find a bidirectional relationship between stock market development and inflation. Similar results were found for African countries where inflation brought volatility to the capital market (Iddrisu et al., 2019), and European countries (Fuinhas et al., 2019). Any economy with high inflation refers to a time of instability. This measure can be used to assess social welfare (e.g., Donayre and Panovska, 2018; Nucera, 2017). Little or much inflation directly impacts the economy, and public measures of central banks do not always cherish economic well-being. 
The results for the development of the financial sector support two kinds of behaviour. By one hand, bidirectional relationship between stock market development and GDP. For example, Fuinhas et al. (2019) studying the European countries found the same bidirectional relationships between the development of the financial sector and stock market development. By the other hand, stock market development being only caused by inflation, which corroborates the nature of the variable (autoregressive), being the sector strongly dependent only on itself. In future research, this variable is always a strong candidate to be submitted to forecasts.

There are two ways that the banking sector affects economic development, financial intermediation and giving liquidity through credit (Ribeiro, 2006). Still, in a more stable scenario provided by rich economies, the risk of default on loans falls. Banks can also operate at lower interest rates, thus attracting more capital. This section showed the possible explanations for bidirectionality between the variables, and the next section will show the conclusion of this investigation.

\section{Conclusion}

This paper focuses on a panel of 16 high-income countries over a period from 2001 to 2016. A PVAR model was used since the results were consistent with the existence of endogeneity and cointegration. They were performed panel Granger causality tests, impulse-response functions, and forecast error variance decomposition.

The variables market capitalisation of listed domestic companies and turnover ratio were the variables chosen to create stock market Development meanwhile domestic credit to the private sector, and domestic credit provided by the financial sector were selected to develop Banking Sector Development. The variables were created using the PCA method. 
In the literature review, four theories on the causality between variables are highlighted. We have found the causality between real GDP per capita and inflation, real GDP per capita and stock market development, real GDP per capita and banking sector development, inflation and stock market development, and between banking sector development and inflation. This confirms the feedback theory.

We also see the bidirectional relationship between Stock Market Development and Banking Sector Development (this follows the supply-leading theory). This supports the supply-leading theory. Through the impulse-response functions, we can conclude that all variables return to zero after a shock in the maximum of ten years.

The empirical method allowed to analyse the set of high-income countries, as they are a homogeneous group, with valued currencies and the ability to influence economies around the world, the study is pertinent. Besides, the countries are susceptible to similar economic impacts given their characteristics. It is in the scientific interest that in future studies countries will be analysed individually. With the availability of more data, it would be interesting to integrate more countries presented here. Besides these results can be used as a basis to compare with the results of new studies with other groups of countries or economic blocs.

\section{Compliance with Ethical Standards}

Funding: This study was funded by CeBER R\&D unit funded by national funds through FCT Fundação para a Ciência e a Tecnologia, I.P., project UIDB/05037/2020.

Conflict of Interest: The authors declare that they have no conflict of interest.

Ethical approval: This article does not contain any studies with human participants or animals performed by any of the authors. 


\section{References}

Abrigo M. R. M., Love I., (2015). Estimation of Panel Vector Autoregression in Stata: A Package of Programs. The University of Hawai'i at Mānoa Department of Economics. URL: http://www.economics.hawaii.edu/research/working.papers/WP16-02.pdf.

Ang J. B., (2008). Survey of recent developments in the literature of finance and growth. Journal of Economic Surveys, 22(3):536-576. doi: https://doi.org/10.1111/j.1467-6419.2007.00542.x.

Antonakakis N., Chatziantoniou L., Filis G., (2017). Energy consumption, CO2 emissions, and economic growth: An ethical dilemma. Renewable and Sustainable Energy Reviews, 68(1):808-824. https://doi.org/10.1016/j.rser.2016.09.105.

Arellano M., Bover O., (1995). Another look at the instrumental variable estimation of error components models. Journal of Econometrics, 68:29-51. doi: https://doi.org/10.1016/0304-4076(94)01642-D.

Barro R. J., (1996). Determinants of economic growth: a cross-country empirical study. National Bureau of Economic Research, 698:1-118. doi. 10.3386/w5698.

Bartlett M. S., (1950). Tests of significance in factor analysis. British Journal of Statistical Psychology, 3(2):77-85. doi: https://doi.org/10.1111/j.2044-8317.1950.tb00285.x.

Beck T., Levine R., (2004). Stock Markets, banks, and growth: Panel evidence. Journal of Banking and Finance, 28(3):423-442. doi: https://doi.org/doi:10.1016/S0378-4266(02)00408-9.

Beck T., Levine R., Loayza N., (2000). Finance and the Sources of Growth. Journal of financial economics, 58(1):261-300. doi: https://doi.org/10.1016/S0304-405X(00)00072-6.

Belsley D. A., Kuh E., Welsch E. R., (1980). Regression Diagnostics: Identifying Influential Data and Sources of Collinearity. New York: Wiley. doi: 10.1002/0471725153.

Belucio, M., Lopes, C. M., Fuinhas, J. A. \& Marques, A. C. (2019). Energy-growth nexus, domestic credit and environmental sustainability: A panel causality analysis. In: Fuinhas, J. A., Marques, A. C (Eds.) The Extended Energy-Growth Nexus (pp.173- 197). Amsterdam. Elsevier. doi: https://doi.org/10.1016/B978-0-12-815719-0.00006-1.

Binder M., Hsiao C., Pesaran M. H., (2005). Estimation and inference in short panel vector autoregressions with unit roots and cointegration. Econometric Theory, 21(4):795-837. URL: www.jstor.org/stable/3533397. 
Boyd J. H., Levine R., Smith B. D., (2001). The impact of inflation on financial sector performance. Journal of Monetary Economics, 47(2):221-248. doi: https://doi.org/10.1016/S0304-3932(01)00049-6.

Bruno M., Easterly W., (1998). Inflation crises and long-run growth. Journal of Monetary Economics, 41(1)3-26. doi: https://doi.org/10.1016/S0304-3932(97)00063-9.

Canova F., Ciccarelli M., (2009). Estimating multi-country VAR models. International. Economic Review 50:929-959. doi: https://doi.org/10.1111/j.1468-2354.2009.00554.x.

Cheng S. Y., (2012). Substitution or complementary effects between banking and stock markets: Evidence from financial openness in Taiwan. Journal of International Financial Markets, Institutions and Money, 22(3):508-520. doi: https://doi.org/10.1016/j.intfin.2012.01.007.

Chow W. W., Fung M. K., (2011). Financial development and growth: A clustering and causality analysis. Journal of International Trade and Economic Development, 35(3):1-24. doi: https://doi.org/10.1080/09638199.2011.570364.

Coşkun Y., Seven Ü., Ertuğrul H. M., Ulussever T., (2017). Capital market and economic growth nexus: Evidence from Turkey. Central Bank Review, 17(1):19-29. doi: https://doi.org/10.1016/j.cbrev.2017.02.003.

Dickey D. A., Fuller W. A., (1979). Distribution of the estimators for autoregressive time series with a unit root. Journal of the American Statistical Association, 74(366):427-431. URL: https://www.jstor.org/stable/2286348.

Donayre L., Panovska I., (2018). US wage growth and nonlinearities: The roles of inflation and unemployment. Economic Modelling, 68:273-292. doi: https://doi.org/10.1016/j.econmod.2017.07.019.

Duttagupta R., Cashin M. P., (2008). The anatomy of banking crises. International Monetary Fund.8(93):1-39. ISBN/ISSN: 9781451869545/1018-5941.

Eng Y., Habibullah M. S. (2011). Financial development and economic growth nexus: another look at the panel evidence from different geographical regions. Banks and Bank Systems, 6(1):62-71. ISSN 1991-7074.

Enisan A., Olufisayo O., (2009). Stock Market Development and Economic Growth: Evidence from seven sub-Sahara African countries. Journal of Economics and Business 61(2):162-171. doi: https://doi.org/10.1016/j.jeconbus.2008.05.001. 
Fink G., Haiss P., Vuksic G., (2009). Contribution of financial market segments at different stages of development: Transition, cohesion and mature economies compared. Journal of Financial Stability, 5(4):431-455. doi: https://doi.org/10.1016/j.jfs.2008.05.002.

Fischer S., (1993). The role of macroeconomic factors in growth. Journal of monetary economics, 32(3):485-512. doi: https://doi.org/10.3386/w4565.

Francis B. B., Ofori E., (2015). Political regimes and stock market development. Eurasian Economic Review, 5(1):111-137. doi: https://doi.org/10.1007/s40822-015-0018-5.

Fuinhas, J. A., Filipe, M., Belucio, M., \& Marques, A. C. (2019) The nexus between financial development and economic growth: An European Countries evidence. Journal of Economics Studies and Research, 2019(2019), Article ID 790582. doi: 10.5171/2019.790582.

Hamilton J., (1994). Time series analysis. Prentice-Hall New Jersey, pp.837-900.

Hansen L. P., (1982). Large sample properties of generalized method of moments estimators. Econometrica, 50(4)1029-1054. URL: http://www.jstor.org/stable/1912775.

Hassan M. K., Sanchez B., Yu J. S., (2011). Financial development and economic growth: New evidence from panel data. The Quarterly Review of economics and finance, 51(1):88-104. doi: https://doi.org/10.1016/j.qref.2010.09.001.

Herwartz H., Walle Y. M., (2014). Determinants of the link between financial and economic development: Evidence from a functional coefficient model. Economic Modelling, 37: 417-427. doi: https://doi.org/10.1016/j.econmod.2013.11.029.

Holtz-Eakin D., Newey W., Rosen H., (1988). Estimating Vector Autoregressions with Panel Data. Econometrica, p.1371-1395. doi: https://doi.org/0012-9682(198811)56:6<1371:EVAWPD>2.0.CO;2-V.

Hou H., Cheng Y., (2010). The roles of stock market in the finance-growth nexus: time series cointegration and causality evidence from Taiwan. Applied Financial Economics, 20(12):975-981. doi: https://doi.org/10.1080/09603101003724331.

Hsueh S., Hu Y., Tu C., (2013). Economic growth and financial development in Asian countries: A bootstrap panel Granger causality analysis. Economic Modelling, 32(3):295-301. doi: https://doi.org/10.1016/j.econmod.2013.02.027.

Huang H. C. R., Yeh C. C., (2017). Level, structure, and volatility of financial development and inflation targeting. Journal of Empirical Finance, 44:108-124. doi: https://doi.org/10.1016/j.jempfin.2017.09.006. 
Hung F.-S., (2003). Inflation, financial development, and economic growth. International Review of Economics \& Finance, 12(1): 45-67. doi: https://doi.org/10.1016/S1059-0560(02)00109-0.

Iddrisu A.-K., Otoo D., Iddrisu W. A., Ankamah S., (2019). Modeling and Forecasting of Ghana's Inflation Volatility. American Journal of Industrial and Business Management, 9:930-949. ISSN Online: 2164-5175.

Jalil A., Feridun M., Ma Y., (2010). Finance-growth nexus in China revisited: New evidence from principal components and ARDL bounds tests. International Review of Economics and Finance, 19(2):189-195. doi: https://doi.org/10.1016/j.iref.2009.10.005.

Kaise H. F., (1970). A second generation little jiffy. Psychometrika, 35(4):401-415. doi: https://doi.org/10.1007/BF02291817.

Kar M., Nazlioglu S., Agir H., (2011). Financial development and economic growth nexus in the MENA countries: Bootstrap panel granger causality analysis. Economic Modelling, pp.685-693. doi: https://doi.org/10.1016/j.econmod.2010.05.015.

Kim D. H., Lin S. C., (2010). Dynamic relationship between inflation and financial development. Macroeconomic Dynamics, 14(3):343-364. doi: https://doi.org/10.1017/S1365100509090312.

Koengkan M., Fuinhas J. A., Losekann L. D., (2019). The relationship between economic growth, consumption of energy, and environmental degradation: renewed evidence from Andean community nations. Environment Systems and Decisions, 39(1):95-107. doi: https://doi.org/10.1007/s10669-0189698-1.

Koengkan M., Fuinhas J. A., Vieira I., (2020). Effects of financial openness on renewable energy investments expansion in Latin American countries. Journal of Sustainable Finance \& Investment, 10(1):65-82. doi: https://doi.org/10.1080/20430795.2019.1665379.

Kolapo T., Adaramola O., (2012). The impact of the Nigerian Capital Market on Economic Growth (1990-2010). International Journal of Developing Societies, 1:11-19. doi: https://doi.org/10.11634/21681783150436.

Kroop G., Korobilis D., (2016). Model Uncertainty in Panel Vector Autoregressive Models. European Economic Review, 81:115-131. doi: 10.1016/j.euroecorev.2015.09.006.

Law S. H., Singh N., (2014). Does too much finance harm economic growth? Journal of Banking \& Finance, 41:36-44. doi: https://doi.org/10.1016/j.jbankfin.2013.12.020. 
Levine R., (1997). Financial development and economic growth: views and agenda. Journal of economic literature, 35(2):688-726. URL: https://pascal.iseg.utl.pt/ aafonso/eif/pdf/Levine.pdf.

Liu X., Sinclair P., (2008). Does the linkage between stock market performance and economic growth vary across Greater China? Applied Economics Letters, 15:505-508. doi: https://doi.org/10.1080/13504850500426277.

Love I., Zicchino L., (2006). Financial development and dynamic investment behaviour: evidence from panel VAR. The Quarterly Review of Economics and Finance, 46(2):190-210. doi: https://doi.org/10.1016/j.qref.2005.11.007.

Lucas R. E., (1988). On the mechanics of economic development. Journal of monetary economics, 22(1):3-42. doi: https://doi.org/10.1016/0304-3932(88)90168-7.

Lutkephol H., (2005). New Introduction to Multiple Time Series Analysis, Springer-Verlag Berlin Heidelberg, 21-764. ISBN: 978-3-540-27752-1.

Macchiarelli C., (2013). Similar GDP-inflation cycles. An application to CEE countries and the euro area. Research in International Business and Finance, 27(1):124-144. doi: https://doi.org/10.1016/j.ribaf.2012.08.008.

Maddala G. S., Wu S., (1999). A comparative study of unit root tests with panel data and a new simple test, Oxford Bulletin of Economics and Statistics, 61(Special Issue): 631-652.

Marques L. M., Fuinhas J. A., Marques A. C., (2013). Does the stock market causa economic growth? Portuguese evidence of economic regime change. Economic Modelling, 32:316-324. doi: http://dx.doi.org/10.1016/j.econmod.2013.02.015.

Menyah K., Nazlioglu S., Wolde-Rufael Y., (2014). Financial development, trade openness and economic growth in African countries: New insights from a panel causality approach. Economic Modelling, 37(2):386-394. doi: https://doi.org/10.1016/j.econmod.2013.11.044.

Mukhopadhyay B., Pradhan R. P., Feridun M., (2011). Finance-growth nexus revisited for some Asian countries. Applied Economics Letters, 18(16):1527-1530. doi: https://doi.org/10.1080/13504851.2010.548771.

Naceur B. S., Ghazouani S., (2007). Stock markets, banks and economic growth: Empirical evidence from the MENA region. Research in International Business and Finance, 21(2):297-315. doi: https://doi.org/10.1016/j.ribaf.2006.05.002. 
Nucera F., (2017). Unemployment fluctuations and the predictability of currency returns. Journal of Banking \& Finance, 84:88-106. doi: https://doi.org/10.1016/j.jbankfin.2017.07.007.

Odhiambo N. M., (2010). Finance-investment-growth nexus in South Africa: an ARDL-bounds testing procedure. Economic Change and Restructuring, 43(3):205-219. doi: https://doi.org/10.1007/s10644010-9085-5.

Owusu L. E., Odhiambo M. N. (2014). Financial liberalization and economic growth in Nigeria: An ARDL-bounds testing approach. Journal of Economic Policy Reform, 17(2):164-177. doi: https://doi.org/10.1080/17487870.2013.787803.

Panopoulou E., (2009). Financial variables and euro area growth: A non-parametric causality analysis. Economic Modelling 26(6):1414-1419. doi: https://doi.org/10.1016/j.econmod.2009.07.013.

Pesaran M. H., (2004). General diagnostic tests for cross-section dependence in panels. The University of Cambridge, Faculty of Economics. Cambridge Working Papers in Economics, n. 0435. doi: https://doi.org/10.17863/CAM.5113.

Petkovski M., Kjosevski J., (2014). Does banking sector development promote economic growth? An empirical analysis for selected countries in Central and South Eastern Europe. Economic researchEkonomska istraživanja, 27(1):55-66. doi: https://doi.org/10.1080/1331677X.2014.947107.

Phillips P. C. B., Perron P., (1988). Testing for a Unit Root in Time Series Regression. Biometrika. 75(2):335-346. doi: 10.1093/biomet/75.2.335.

Pradhan R. P., (2013). The Determinants of Long-Run Finance Development: The ARDL Bound Testing Approach. Prajnàn: journal of social and management sciences, 42(1):145-163. ISSN 0970-8448.

Pradhan R. P., Arvin M. B., Norman N. R., Hall J. H., (2014b). The dynamics of banking sector and stock market maturity and the performance of Asian economies: Time series evidence. Journal of Economic and Administrative Sciences, 30(1):16-44. doi: https://doi.org/10.1108/JEAS-06-2013-0022.

Pradhan R. P., Arvin M. B., Samadhan B., Tanejha S., (2013). The impact of stock market development on inflation and economic growth of 16 Asian countries: A panel VAR approach. Applied Econometrics and International Development, 13(1):203-220. URL: http://www.usc.es/economet/journals1/aeid/aeid13116.pdf.

Pradhan R. P., Arvin M. B., Bahmani S., (2015). Causal nexus between economic growth, inflation, and stock market development: The case of OECD countries. Global Finance Journal, 27:98-111. doi: 
Pradhan R. P., Arvin M. B., Bahmani S., Hall J. H., Norman N. R., (2017). Finance and growth: Evidence from the ARF countries. The Quarterly Review of Economics and Finance, 66:136-148. doi: https://doi.org/10.1016/j.qref.2017.01.011.

Pradhan R. P., Arvin M.B., Hall J. H., Bahmani S., (2014a). Causal nexus between economic growth, banking sector development, stock market development, and other macroeconomic variables: The case of ASEAN countries. Review of Financial Economics, 23(4):155-173. doi: https://doi.org/10.1016/j.rfe.2014.07.002.

Pradhan R. P., Arvin M. B., Norman N. R., Nishigaki Y., (2014c). Does banking sector development affect economic growth and inflation? A panel cointegration and causality approach. Applied Financial Economics, 24(7):465-480. doi: https://doi.org/10.1080/09603107.2014.881968.

Ribeiro C. T., Carvalho C. E., (2006). Do Microcrédito às microfinanças: desempenho financeiro, dependência de subsídios e fontes de financiamento: uma contribuição à análise da experiência brasileira. São Paulo: Fapesp; Educ. ISBN-13: 978-8528303445.

Rousseau P. L., Yilmazkuday H., (2009). Inflation, financial development, and growth: A trilateral analysis. Economic Systems, 33(4):310-324. doi: https://doi.org/10.1016/j.ecosys.2009.06.002.

Schumpeter J. A., (1911). The Theory of Economic Development. Cambridge: Harvard University Press, pp.1-255. ISBN 9780674879904.

Serena N., Perron P., (2001). Lag length selection and the construction of unit root tests with good size and power. Econometrica, 69(6):1519-1554. URL: http://www.jstor.org/stable/2692266.

Seven Ü., Yetkiner H., (2016). Financial intermediation and economic growth: Does income matter? Economic Systems, 40(1):39-58. doi: https://doi.org/10.1016/j.ecosys.2015.09.004.

Sigmund, M., Ferstl R., (2017). Panel Vector Autoregression in R with the Panelvar Package. URL: https://ssrn.com/abstract=2896087.

Suhaibu I., Harvey S. K., Amidu M., (2017). The impact of monetary policy on stock market performance: Evidence from twelve (12) African countries. Research in International Business and Finance, 42:1372-1382. doi: https://doi.org/10.1016/j.ribaf.2017.07.075.

Wolde-Rufael Y., (2009). Re-examining the financial development and economic growth nexus in Kenya. Economic Modelling, 26(6):1140-1146. doi: https://doi.org/10.1016/j.econmod.2009.05.002. 
World Bank Open Data (2019). URL: http://www.worldbank.org/.

Yu J. S., Hassan M.K., Sanchez B., (2012). A re-examination of financial development, stock markets development and economic growth. Applied Economics, 44(27):3479-3489. doi: https://doi.org/10.1080/00036846.2011.577019.

Zhu A., Ash M., Pollin R., (2004). Stock market liquidity and economic growth: a critical appraisal of the Levine/Zervos model. International Review of Applied Economics, 18(1): 63-71. doi: https://doi.org/10.1080/0269217032000148645. 